\title{
How does legacy create sticking points for environmental management? Insights from challenges to implementation of the ecosystem approach
}

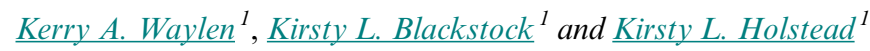

\begin{abstract}
There are many recommendations for environmental management practices to adopt more holistic or systems-based approaches and to strengthen stakeholder participation. However, management practices do not always match or achieve these ideals. We explore why theory may not be reflected by practice by exploring experiences of projects seeking to implement the ecosystem approach, a concept that entails participatory holistic management. A qualitative inductive approach was used to understand the processes, achievements, and challenges faced by 16 projects across the British Isles. Many projects made significant progress toward their goals, yet failed to achieve fully participatory holistic management. Many of the challenges that contributed to this failure can be explained in terms of the legacy effects of previous projects and the wider social-ecological system. These legacy effects do not necessarily imply a fixed path dependency or lock-in. We therefore call these effects sticking points. Drawing on the literature on institutional analysis and knowledge production, we distinguish three main types of sticking point: (1) institutional, arising from previous ways of working; (2) cognitive, arising from ways of framing and knowing; and (3) political, arising from pre-existing power relations. These sticking points may interact. For example, attempts to promote systems thinking and management may be impeded by a tendency for reductionist thinking, itself reinforced by the constraints on prioritization that arise from pre-existing statutory targets. These influences often arise from aspects of societal and institutional context beyond the control of any individual project. Stickiness is not necessarily all bad, but often acts to constrain the "opening up" away from previous approaches. Because the longterm success of natural resource management is argued to depend on more integrated, participatory, and holistic environmental management, we argue that these sticking points demand more explicit attention in both research and practice.
\end{abstract}

Key Words: adaptive management; conservation; institutional inertia; participation; pathways; systems thinking

\section{INTRODUCTION}

Recent decades have seen a fundamental change in understanding how environmental problems should be tackled. Past top-down and technocratic approaches have been critiqued: In response, a new discourse emphasizes the need to "open up" to more holistic and participatory approaches (Sterling et al. 2010, Miller et al. 2012). The participation of other interested parties is advocated because involving and incorporating stakeholder views is thought to contribute to more informed, effective, and equitable outcomes (e.g., Reed 2008, Paavola and Hubacek 2013). Systemic or holistic approaches are also promoted because environmental management is trying to intervene in complex and dynamic socialecological systems in which the human and natural are intertwined (Sterling et al. 2010, Miller et al. 2012). However, although these ideas have now been around for several decades, attempts to implement them achieve variable outcomes, and many environmental problems continue to worsen. There has been much work to understand the challenges facing environmental management practices and projects, but little understanding of how to overcome these challenges. Here, we ask if the understanding of why problems persist and how projects "get stuck" would be aided by considering legacy effects.

Any attempt to manage natural resources will necessarily build on and be shaped by social and institutional settings, including the legacy of any prior interventions (Wilshusen et al. 2002). Some comparative analyses have attempted to disentangle the effects of project design from selected aspects of context (e.g., Brooks et al. 2012), and a few studies have explicitly noted legacy effects as impeding project outcomes (e.g., Meer and Schnurr 2013). These analyses sometimes note that the legacy of previous projects and ways of working can cause management practices to differ only incrementally from previous approaches (e.g., Kates et al. 2012). However, in general, there has been little explicit attention as to how the legacy of past settings and projects may shape attempts to implement new approaches. It is therefore timely to ask if legacy effects are a useful way to understand progress and challenges in attempts to implement new participatory and holistic environmental management approaches.

Our overall objective is to explore if and how legacy effects can aid understanding of the opportunities and challenges associated with attempts to change environmental management practices. This exploration is structured around two objectives: (1) to review why legacy effects may be an important influence on attempts to implement new participatory and holistic environmental management approaches, and (2) to explore how and when legacy effects are likely to influence the processes and outcomes of attempts to implement new environmental management approaches. We do this by reviewing the literature on these effects and by exploring experiences of projects that attempted to implement a management concept called the "ecosystem approach". This concept was adopted by the Convention on Biological Diversity to achieve "the integrated management of land, water and living resources that promotes conservation and sustainable use in an equitable way" (CBD 2000). The ecosystem approach builds on pre-existing management concepts such as ecosystem-based management (e.g., Lackey 1998) and community-based conservation (e.g., Western et al. 1994). It entails understanding natural system properties and processes, taking into account the benefits and services to humans arising from nature (ecosystem services), and understanding systems as 
dynamic while promoting stakeholder engagement and coordination between partners, similar to adaptive comanagement (Armitage et al. 2009). The ecosystem approach is thus ambitious (Waylen et al. 2014) because it combines recommendations for systems-based approaches together with arguments for decentralization and involvement of stakeholders and their knowledge (Fish 2011).

There is currently widespread interest in the ecosystem approach from policy makers (e.g., within the UK; DEFRA 2011), as well as a growing body of scientific literature on this and related terms and concepts (Waylen et al. 2014). However, most established policy and practice has been founded in more traditional ways of thinking of about environmental management that have been based in the technocratic, exclusionary paradigm (Adams 2009). Projects that attempt to adopt an ecosystem approach thus exemplify attempts to change environmental management and so are an ideal means by which to explore how attempts to introduce new and less technocratic approaches play out in practice.

\section{RATIONALE FOR STUDYING LEGACY EFFECTS}

Many social science fields agree on the need to understand and analyze problems in terms of institutions, that is, the formal and informal rules that influence behavior (North 1990). This "new institutionalism" has also influenced the understanding of attempts to tackle environmental problems, for example, highlighting critical assumptions about the rationale and outcomes of management interventions (e.g., Brown 2002, Vatn 2010), and being used to provide constructive recommendations for new management approaches (e.g., Imperial 1999). However, attempts to understand environmental management efforts are less often explicitly framed around legacy effects, even though this is one important focus of new institutionalism (Hall and Taylor 1996).

There are several ways in which the effect of the past on the present can be labeled and understood. Historical institutionalism, as its name suggests, has a particular focus on the effect of "critical junctures and long-term processes" on later institutional arrangements and unintended consequences (Skocpol and Pierson 2002). Potential influences on later institutional arrangements are wide-ranging and include interests and power, culture, and worldviews (Hall and Taylor 1996). Other social and management sciences also refer to the effect of the past in various ways, but whenever these effects cause a strong constraint on the evolution of later institutional arrangements, they are typically referred to as entailing path dependency (North 1990). The most extreme form of this is called lock-in, whereby past systems or ways of working are entirely predetermined by previous arrangements. A classic example is the persistence of the Qwerty keyboard, despite its mechanical inefficiency (David 1985).

The ideas of path dependency and lock-in (and the need to avoid them) underpin much work on economic development (Boettke et al. 2008) and have been used to frame the understanding of progress in specific projects or programs of reform such as in the healthcare sector (Wilsford 1994, Thrane et al. 2010, Gómez 2011). In these studies, the institutional inertia, or "stickiness", that arises from legacy effects is usually seen as a bad thing to be overcome, although it is allowed that legacy can have positive effects in that it provides something for new efforts to learn from and build on (Schienstock 2007).
Studies of environmental management rarely make explicit reference to these works, even though attempts to operationalize management concepts are often thought to fall short of their original ideals (e.g., Dressler et al. 2010) and legacy effects may help explain why. Within the environmental literature, there have been some references to these concepts: path dependency has been referenced most often (e.g., Berkes 2007), whereas stickiness has been mentioned by Young (2002). However, these labels are rarely discussed or unpacked. The challenges to be overcome are more often discussed and explored in terms of inherent difficulties such as those associated with adopting systemic approaches (e.g., Miller et al. 2012) or promoting stakeholder involvement (Reed 2008). While these may indeed be inherently difficult, perhaps because they entail greater complexity, challenges may also arise simply because they are new and differ from prior ways of working (Harries and Penning-Rowsell 2011, Rogers et al. 2013). Therefore, it is useful to consider if explicitly framing and studying new interventions in terms of legacy effects could help to improve the understanding of environmental management and points of resistance to change.

At present, the best insight into the applicability of these concepts comes from the literature on water management. Attempts to adopt less technocratic approaches have experienced constraints arising from both pre-existing regulatory systems and difficulties in acquiring new knowledge (Kirk et al. 2007), and powerful political pressures at all levels of society may act to oppose change, even when this is an explicit policy goal (Harries and PenningRowsell 2011). Only a few studies framed in these terms exist, but studies from Scotland, UK (Kirk et al. 2007, Harries and PenningRowsell 2011), the United States (Ingram and Fraser 2006), and Israel (Fischhendler and Heikkila 2010) suggest that incumbent interests and problem framing, though less tangible than physical infrastructure, can produce strong resistance to change. These insights are grounded in work on knowledge and power, where knowledge includes not only explicit knowledge (for example, specific facts or information), but also tacit knowledge and worldviews that powerfully shape how issues are framed and understood (Fazey et al. 2006). Power is any capacity to influence action, and its use to reinforce incumbent interests may or may not be explicit or deliberate (Stirling 2008). The communication and use of different types of knowledge tend to encourage and aid powerful actors, who may often act to "close down" or constrain change (Stirling 2012).

More positively, recognition of legacy issues can also offer ways to promote change or transition in water management (Meijerink and Huitema 2009, Huitema and Meijerink 2010). The idea of finding pathways that can achieve change has also been influential beyond the water management literature. In particular, it has informed recommendations for achieving transformation or transition to new governance and management approaches (e.g., Pahl-Wostl et al. 2010). It has also informed a recent pathways approach designed to explain why environmental governance often retreats from handling the complexity of systems and multiple stakeholder views and how this can be overcome (Leach 2010, Leach et al. 2010a). These concepts are receiving much interest, and they implicitly or explicitly build on the idea that legacy effects can impede progress. However, the legacy effects themselves receive less explicit attention. 
In summary, the existing literature suggests that a focus on legacy effects may be useful, yet is an under-used way of understanding why attempts to introduce participatory and holistic environmental management are proving challenging. To do this, a theoretically grounded analytical framework is needed because past use of terms such as pathways and lock-in has sometimes been criticized for lacking depth or consistency in framing (e.g., Greener 2005, Kay 2005).

Many frameworks share a distinction between structure and/or institutions, knowledge, and power. Grabher (1993) made a particularly influential typology of three types of lock-in: functional, i.e., decreased investment in infrastructure permitting adaptation; cognitive, i.e., a tendency to favor one problem framing rather than alternative perspectives; and political, i.e., preferring to reinforce existing interests. Grabher's ideas were developed in relation to understanding organizational development, but have since been applied to other topics and at other levels of analysis (e.g., Uzzi 1996, Kaufmann and Tödtling 2001). The three types of lock-in also have some similarities with three pressures distinguished by the pathways approach: cognitive, institutional, and political (Leach et al. 2010b). Therefore, it may be productive to explore legacy in terms of these three issues.

We do not adopt the terms lock-in or pathway because we do not presuppose how legacy effects may work to affect projects; these terms may not necessarily dictate fixed paths or constraints. Instead, we use stickiness (von Hippel 1994, Young 2002) as a term that can help to explain resistance to change, yet does not prohibit or proscribe particular forms of change. We distinguish three types of sticking point: (1) institutional, i.e., formal rules and informal norms arising from previous ways of working; (2) cognitive, i.e., sticking points arising from ways of framing and knowing; and (3) political, i.e., sticking points arising from preexisting power relations and interests. Based on the literature, we expect that some of these issues may interact, but also that this typology may serve as a useful guide for analyzing influences on the progress of participatory and holistic environmental management. We use these concepts to explore the experiences of the 16 ecosystem approach projects described next.

\section{METHODS}

We explore sticking points through a study of attempts to implement the ecosystem approach within the UK and Ireland. Our review did not originally have a specific focus on legacy effects or sticking points; the study design was motivated by a general objective of identifying insights for how to implement the ecosystem approach within Scotland. We next explain the research process that was designed to address this general objective and through which the issue of sticking points arose.

\section{Data collection and analysis}

We identified cases to review by searching the Internet and policy documents for natural resource management initiatives that had been labeled as examples of the ecosystem approach. We found that within these documents, the ecosystem approach was typically understood as something to be implemented at the project level. We searched for projects only within in Scotland, England, Wales, Northern Ireland, and the Republic of Ireland because these regions were likely to share similarities in their social and institutional settings. We searched for projects initiated after the year 2000, the year the ecosystem approach concept was adopted by the Convention on Biological Diversity. We excluded projects if they used the term but did not directly aim to intervene in natural resource management, or if there was no evidence of attempting systemic approaches or participation. We also excluded projects for which little documentary evidence was publically available. Finally, we identified 24 projects that had been labeled as implementing the ecosystem approach and met our criteria. Here, we report only those 16 cases that self-identified as implementing the ecosystem approach.

We collected information about each project in three ways. First, we collated and summarized documentary evidence on the project origins and progress. We then used an in-depth interview with the project contact to check and supplement this information, with a particular focus on exploring experiences of project implementation. Subsequent to the interviews, we asked interviewees to fill in a simple questionnaire on their expectations and experiences of the project in relation to the principles of the ecosystem approach.

The collection of information from documentary evidence and in-depth interviews was influenced by existing arguments about likely challenges faced by natural resource management. A proforma was used to structure information collection from the review of documents. To guide the semi-structured interviews, a topic guide was used that had a greater focus on topics likely to be underreported in documentary evidence (e.g., experiences of coordination challenges). The final main topics included a description of the project objectives and scope; timelines; understanding of and rationale for adopting the ecosystem approach; reflection of what the project had achieved and why; challenges experienced and why; and ideas and recommendations for implementing similar projects (see Appendix 1 for all headings within the proforma and interview guide).

All of our case study project factsheets, interview transcripts, and questionnaire responses were stored and linked using Nvivo 9 software (QSR International, Doncaster, Australia). Our qualitative analysis (Silverman 2004) of the material focused on understanding and explaining experiences and outcomes of case studies of the ecosystem approach using a mixed inductive and deductive approach. The selection of topics reflected a deductive approach (guided by ideas in the literature), and these topics were also used when identifying themes in the data. However, when recording themes in the data (coding in Nvivo), this process was largely inductive and influenced by grounded theory; i.e., the themes coded reflected topics in the data, rather than the just researchers' pre-existing ideas (Strauss and Corbin 1998). Through this process, the issue of sticking points was identified.

Reliability of data analysis was promoted through triangulation, searching for exceptions to our emerging ideas, and member checks. In member checks, interviewees were given the opportunity to check and update our summary information and understanding of the projects and had an opportunity to comment on the overall project findings as summarized in a report. Furthermore, early findings were discussed and found to resonate with other academics and practitioners attending a dedicated conference session (Howard et al. 2013). We illustrate these findings using quotations taken from the interviews, labeled by their anonymized project label (e.g., project A). 
Table 1. Basic attributes of the 16 projects used as cases.

\begin{tabular}{|c|c|c|c|c|c|c|}
\hline $\begin{array}{l}\text { Proj- } \\
\text { ect }\end{array}$ & $\begin{array}{c}\text { Time } \\
\text { scale }(\mathrm{yr})\end{array}$ & Management lead & Source of funding & Focal issue & Scale $\left(\mathrm{km}^{2}\right)$ & Prior project at same scale \\
\hline $\bar{A}$ & $\leq 1$ & Statutory agency & $\begin{array}{l}\text { Public (national } \\
\text { government) }\end{array}$ & $\begin{array}{l}\text { Manage multiple habitats for multiple } \\
\text { benefits in upland landscape }\end{array}$ & $100-500$ & None \\
\hline B & $\leq 1$ & Statutory agency & $\begin{array}{l}\text { Public (multiple } \\
\text { agencies) }\end{array}$ & $\begin{array}{l}\text { Manage multiple habitats for multiple } \\
\text { benefits in upland landscape }\end{array}$ & $>500$ & $\begin{array}{l}\text { A visioning exercise for } \\
\text { future land management }\end{array}$ \\
\hline $\mathrm{C}$ & $\leq 2$ & Statutory agency & $\begin{array}{l}\text { Public (multiple } \\
\text { agencies) }\end{array}$ & $\begin{array}{l}\text { Manage multiple habitats and resources } \\
\text { for lake restoration to deliver multiple } \\
\text { benefits }\end{array}$ & $100-500$ & $\begin{array}{l}\text { A partnership for lake } \\
\text { restoration }\end{array}$ \\
\hline $\mathrm{D}$ & $\leq 2$ & Statutory agency & $\begin{array}{l}\text { No new funding } \\
\text { used }\end{array}$ & $\begin{array}{l}\text { Manage multiple habitats and resources } \\
\text { for multiple benefits in upland landscape }\end{array}$ & $10-100$ & None \\
\hline $\mathrm{E}$ & $\leq 2$ & $\begin{array}{l}\text { Nongovernmental } \\
\text { organization }\end{array}$ & $\begin{array}{l}\text { Public (national } \\
\text { government) }\end{array}$ & $\begin{array}{l}\text { Restore a catchment in an urban } \\
\text { landscape to deliver multiple benefits }\end{array}$ & $100-500$ & $\begin{array}{l}\text { A catchment management } \\
\text { initiative }\end{array}$ \\
\hline $\mathrm{F}$ & $\leq 2$ & $\begin{array}{l}\text { Nongovernmental } \\
\text { organization }\end{array}$ & $\begin{array}{l}\text { Public (multiple } \\
\text { agencies) }\end{array}$ & $\begin{array}{l}\text { Manage wetlands and other habitats for } \\
\text { floodplain restoration to improve water } \\
\text { quality and deliver other benefits }\end{array}$ & $\leq 1$ & None \\
\hline G & $\leq 3$ & University & Public (European) & $\begin{array}{l}\text { Manage multiple habitats for catchment } \\
\text { restoration to improve water quality and } \\
\text { deliver other benefits }\end{array}$ & $>500$ & None \\
\hline $\mathrm{H}$ & $\leq 3$ & Water company & Private & $\begin{array}{l}\text { Manage multiple habitats for multiple } \\
\text { benefits, particularly water quality and } \\
\text { flows, in upland landscape }\end{array}$ & $10-100$ & $\begin{array}{l}\text { A partnership for upland } \\
\text { restoration }\end{array}$ \\
\hline I & $\leq 3$ & Water company & $\begin{array}{l}\text { Mixed private and } \\
\text { public sector }\end{array}$ & $\begin{array}{l}\text { Manage multiple habitats for catchment } \\
\text { restoration to deliver multiple benefits }\end{array}$ & $>500$ & None \\
\hline $\mathrm{J}$ & $\leq 4$ & Statutory agency & $\begin{array}{l}\text { Public (national } \\
\text { government) }\end{array}$ & $\begin{array}{l}\text { Develop more integrated and sustainable } \\
\text { management of marine and coastal areas }\end{array}$ & $>500$ & None \\
\hline K & $\leq 4$ & Mix of agencies & $\begin{array}{l}\text { Public (national } \\
\text { government) }\end{array}$ & $\begin{array}{l}\text { Manage multiple habitats for catchment } \\
\text { restoration to improve water quality and } \\
\text { deliver other benefits }\end{array}$ & $>500$ & None \\
\hline $\mathrm{L}$ & $\leq 4$ & Mix of agencies & $\begin{array}{l}\text { Public (multiple } \\
\text { agencies) }\end{array}$ & $\begin{array}{l}\text { Manage multiple habitats for catchment } \\
\text { restoration to deliver multiple benefits }\end{array}$ & $10-100$ & None \\
\hline M & $\leq 5$ & Local authority & $\begin{array}{l}\text { Public (multiple } \\
\text { agencies) }\end{array}$ & $\begin{array}{l}\text { Manage multiple habitats for multiple } \\
\text { benefits in upland landscape }\end{array}$ & $>500$ & None \\
\hline $\mathrm{N}$ & $>5$ & Local authority & $\begin{array}{l}\text { Public (multiple } \\
\text { agencies) }\end{array}$ & $\begin{array}{c}\text { Manage water flows on agricultural land } \\
\text { to improve water quality and deliver } \\
\text { other benefits }\end{array}$ & $\leq 1$ & None \\
\hline $\mathrm{O}$ & $>5$ & Statutory agency & $\begin{array}{l}\text { Public (single } \\
\text { agency) }\end{array}$ & $\begin{array}{c}\text { Manage a coastal area for multiple } \\
\text { benefits }\end{array}$ & $>500$ & $\begin{array}{l}\text { A designated site and its } \\
\text { management project }\end{array}$ \\
\hline $\mathrm{P}$ & $>5$ & Water company & Private & $\begin{array}{l}\text { Manage multiple habitats for water } \\
\text { quality and other benefits in upland } \\
\text { landscape }\end{array}$ & $>500$ & None \\
\hline
\end{tabular}

\section{Project design and attributes}

Of the basic attributes of these 16 projects (Table 1), project scale varied widely, with boundaries influenced by habitats or biophysical attributes, particularly catchment processes, societal units (e.g., local authority boundaries), and/or pre-existing conservation designations. Few of the projects directly built on a prior project operating at the same scale, but when they did, they had the same organizational lead.

Whereas previous approaches to managing these sites had typically focused on meeting single targets (e.g., to conserve a certain species), new projects were open-ended and considered multiple objectives (e.g., conservation targets, agricultural production, water quality objectives, flood regulation, carbon storage, and recreational access). As such, no projects were driven solely by single statutory targets or policies, nor were any projects accompanied by the creation of new statutory targets or designations. However, all projects except project $\mathrm{N}$ encompassed one or more sites designated as protected areas, with whose stipulations they had to comply.

The projects were also characterized by partnerships; even when a single agency or organization led the project, there was always some concern to liaise with other statutory agencies and/or encourage stakeholder engagement. Working in partnership with others was linked to the desire or mandate to consider multiple objectives. Many of these initiatives were publically funded, but private (commercial) funding or co-funding was a significant feature of several water management projects. Funding cycles strongly influenced project time scales, and the majority ran for $\leq 4$ yr. More information about project design and context is available from Waylen et al. (2013). All of these issues and more were considered during the analysis but had no obvious effects that added to our understanding of sticking points and so are not discussed further here. 


\section{RESULTS}

Project achievements and challenges

Both the interviews and documentary evidence indicated that all projects made progress toward fostering environmental management that considers multiple issues with multiple partners and encouraging engagement and interest by local-level stakeholders. However, all projects also encountered multiple obstacles that posed challenges to achieving their goals or fully implementing all aspects of the ecosystem approach.

Many of these challenges relate to issues already discussed in the literature on environmental project management and that had informed our approach to data collection (Appendix 1). Many of the challenges related to working in partnership with others, i.e., the complexity arising from and skills required to coordinate with multiple other organizations. A second set of challenges was in trying to understand multiple issues and their interconnections: Even when project teams felt they were able to do this, they sometimes struggled to encourage partners and stakeholders to think in this way. Both these challenges related to problems of knowledge sharing and communication. The literature on environmental management already discusses many of these challenges (e.g., Folke et al. 2005), in particular, the challenges of stakeholder engagement and working in partnerships (e.g., Reed 2008), and systems thinking (e.g., Rogers et al. 2013).

When exploring these challenges, we frequently encountered issues that related to sticking points arising from the legacy of prior projects or pre-existing institutional arrangements. For example, while working in partnerships is always complex, an interviewee might note that its difficulties were exacerbated by the aptitude and skills of staff, and difficult to accommodate within the bureaucracies of organizations previously used to working independently. Because legacy is often not the explicit focus of the literature on environmental management, we decided to explore this further.

\section{How legacy creates sticking points for project processes and outcomes}

We present our exploration of legacy effects by using the typology of three types of sticking points: institutional, cognitive, and political. We begin by focusing on the most tangible and distinct influences that often arose from pre-existing policy and legislation and that correspond with institutional sticking points. We then consider less tangible influences of cognitive sticking points, political sticking points, and their interactions.

\section{Institutional sticking points}

The concept of institutional sticking points encompasses a wide variety of formal and informal rules. We first consider formal rules, often arising from pre-existing policy and legislation, before discussing the less formal norms of working culture and organizational processes.

Legislation and plans: The most tangible constraint affecting most projects in our sample arose from the legacy effects of pre-existing legislation and initiatives for environmental management. As a minimum, this caused a layering of projects on pre-existing approaches and frameworks for environmental management. In some cases there, were many of these pre-existing initiatives to connect with: "There are an awful lot of other policies, strategies, plans coming out of your ears," (project E). The original concept of the ecosystem approach itself did not explicitly discuss how to connect with other concepts. Thus, for example, in discussions on catchment management, the interviewee for project I reflected, "No-one really knew how the two approaches fitted together." This risked confusion and apathy toward new concepts.

Beyond this layering effect, the pre-existing mandates for natural conservation posed a significant constraint to making new plans. Sites of Special Scientific Interest (SSSIs) are the basic means through which sites are assigned to receive protection for nature conservation in the UK. SSSIs are a product of a 1949 Act that gave government conservation bodies a duty to designate sites containing high-quality natural flora or fauna, rare or endangered species, or key geological or physiological features. Similarly, Natura2000 sites are designated under the European Bird and Habitats Directives and must be managed to achieve "favourable conservation status" as defined in those directives (Ostermann 1998). The fixed targets entailed "are expressed in absolutely rigid terms, so they can't be dynamic, and generally they don't take account of any other ecosystem service delivery," (project B). As the same interviewee recognized, these are legally binding and cannot be ignored: "We can't suddenly say 'oh well, let's forget about the statutory side then'." This clearly conflicts with the idea of adaption over space and time, as required by projects trying to balance societal benefits from nature (ecosystem services) or practice adaptive management.

Funding criteria and duration: Many projects were dependent on full or partial funding from statutory agencies or direct from national government. The funding timelines for these projects reflected pre-existing constraints and public funding cycles; sometimes projects were expected to deliver in as little as $1 \mathrm{yr}$, but more often in 3-4 yr. Although these time scales may be sufficient to address some single-issue, single-organization projects, this was felt to be too short for these new projects. "We only had two years really, well two and a half. If we'd had another six months or a year... we could have done more... time was probably more of a constraint than money," (project G).

Short timelines do not suit projects that need to establish participatory processes, which tend to evolve slowly and unpredictably over time (Reed 2008). "It's a participatory approach, so you have to put time into that, and it does take time, it's not always easy," (project C). The interviewee for project M gave a typical list of the many partners to be engaged:
There's all sorts of administrative divisions within the area. Not just between local councils but at river basins, planning districts, internally within agencies - there are three forest districts within the area. So there's really a lot of stitching together of ... or there's a need to cross existing administrative divisions and existing perceptions of the area in spatial terms.

However, because public funding could not be provided for a longer period, many projects finished just at the point that dialog really began. This problem was compounded by the funding normally only being available for planning. Thus, even if there was time for decision making on new actions and priorities, only existing sources of funding for actions could be used. Quite often, actions to be taken incur costs for land managers, so many made efforts to identify options within Agri-environmental Schemes as a potential source of funding for action. However, these schemes 
have been designed with no reference to the new holistic management approaches or concepts such as ecosystem services. Thus, new priorities might be identified, but could not be achieved unless they happened to fit with the pre-existing priorities of separate schemes. Such challenges are especially difficult to manage when the organizations themselves are not used to cooperating or taking a systemic approach.

Organizational processes: The legacy of delivering less holistic and less participatory projects had influenced the present capacity and ways of working of organizations involved in environmental management, particularly the statutory agencies responsible for conservation, who were also often those expected to lead implementation of the ecosystem approach. To implement the ecosystem approach, relevant skills included the ability to understand natural systems and describe the ecosystem services they support, together with "people skills" for engagement with other partners and stakeholders. Many project staff had no training in using ecosystem service concepts or in stakeholder engagement: the interviewee for project J bluntly stated, "We didn't have those skills." Staff involved in these projects therefore had to acquire these skills or, if possible, hire external contractors. This lead to processes which, to some, felt "torturous... too longwinded, too difficult!" (project B).

An additional challenge came because these project staff worked in departments and organizations that were described as fragmented. For example, the interviewee for marine project $\mathbf{J}$ complained that in addition to having to engage with many local authorities, a substantial challenge came from trying to negotiate the "interface between terrestrial and marine planning." Sectoral and disciplinary boundaries are partially due to separate departments and organizations, but they also represent and arise from less tangible cultures of work. For example, engagement with the private water companies was seen as challenging because, "They work in a very regimented way - because they are corporations, they are private... they've got very different ways of working," (project E). Even within the environmental sector, a problem was noted to arise from a "silo culture" within and between many organizations because that often limited the ability to connect issues: "For too long we have been sectorally focused.... you have to look at all these things in combination. The trouble is it's a lot of things to do: it's very complex," (project F).

In summary, mandatory targets, short time scales, and no funding for new actions all strongly constrained attempts to change environmental management. These sticking points are largely a legacy of institutional structures created to support past projects and priorities. Their less tangible and informal effects may overlap or be intertwined with ways of thinking.

\section{Cognitive sticking points}

Cognitive sticking points are those arising from pre-existing ways of framing and knowing. Although ways of knowing can sometimes be difficult to elicit or illustrate directly, we often felt that these related to the challenges experienced. For example, we have discussed how organizational processes could create institutional sticking points, but these sectorial ways of working also seemed related to a way of thinking, a silo culture, that limited the ability to consider and connect issues. This was likewise for land managers; traditional practices are known to be intertwined and reflect certain values and ways of thinking. For example, the interviewee for project P said that farmers favored "what they've been doing traditionally perhaps for decades.... to do the things they've always done." We understood this to indicate a cognitive sticking point.

In several cases, interviewees directly discussed this issue of people's ideas or framing as being a source of resistance to change. This was ascribed partly to individuals' training, as well as to recent project experience. For example, few project staff had their primary training in social issues or stakeholder engagement skills. Although many had backgrounds in the natural sciences, they were accustomed to considering management in terms of single issues, not multiple ecosystem services. As a result, a single-issue, "tick a box" focus was felt to persist, even though, as the project $\mathrm{N}$ interviewee pointed out, "There's thinking [needed] beyond that." Cognitive sticking points could be detected in the ideas of staff tasked with leading project implementation, and they also arose in the ways of thinking of many of the stakeholders and partners with whom projects attempted to engage. Some project managers felt the general public could see the connections between issues, but it was more tricky for groups organized around a particular issue or interest (e.g., boating in project E) and hence, "For a lot of people...it doesn't come naturally," (project D). As a result, for many project staff and stakeholders, management of single issues seemed much easier to comprehend than holistic and inclusive approaches. The interview for project $\mathrm{F}$ contained a quotation which nicely summarized this: "We're very good at finding technical solutions to specific problems, but this isn't a specific problem, this is a generic problem, and we're not very good at finding generic solutions that are good for everyone."

The persistence of thinking about single environmental issues was manifest in the monitoring programs linked to the projects. Most of these programs continued to assess single issues, e.g., for catchment management: biochemical indicators of water quality. Although some programs might have expanded this slightly, e.g., to consider indicators of general ecological health, no projects in our sample attempted to monitor any social parameters or to link the different indicators to form system understanding.

We cannot prove the source of these challenges in system thinking; separating the inherent challenges of systems thinking from the legacy effects of centuries of reductionist thinking is very difficult (Rogers et al. 2013). However, interviewees agreed that systems thinking was definitely a new notion that was not promoted or attempted by previous projects. Doing anything new is, in and of itself, always difficult (Watson 1971). "It's new, it's inclusive or aiming to be inclusive and comprehensive in its approach, rather than being specific to a particular development or land management issue. I think it's just a bit of a challenge, I suppose," (project A).

A legacy of understanding and describing issues in terms of single species or habitats also meant there were many uncertainties and data gaps about how to describe and use ecosystem service concepts. For example, a project to manage marine systems described the scientific knowledge on these topics as "extremely limited" and reflecting a "fundamental lack of understanding" (project $\mathbf{J}$ ). The difficulties in making a cognitive shift to a systems approach were therefore exacerbated by a lack of information. Another challenge came from a lack of information about how new systemic approaches to management were supposed to connect with previous approaches: Because there were few 
examples of how to "do" the ecosystem approach, no-one understood how new and old "fitted together" (project I). For all groups involved in these projects, this could cause confusion or "add a layer of fuzziness" (project G). Because other approaches and priorities were already clear in some people's minds, the uncertainties could encourage dismissal of the new approach as "just another raft of things to think about" (project K).

In summary, systemic issues seemed inherently difficult to deal with, but these difficulties were contributed to or reinforced by a legacy of managing but also thinking about the environment in terms of single issues or problems. There were indications that these sticking points could be reinforced by questions of power, which might foster an unwillingness to attempt a new way of thinking. This is discussed next.

\section{Political sticking points}

Political sticking points are those arising from pre-existing power relations and a tendency to use power to defend existing interests. Past approaches to environmental management vested power and responsibility in the hands of statutory organizations for conservation and environmental management. This had clearly influenced the choice of organization for leadership of new projects: Only four of the projects in our sample were not lead by the public sector. These projects were attempting to consider and connect a much wider range of issues or scales than previously, so this may have further reinforced the tendency to favor the statutory agencies because smaller or single-issue organizations were often less able or willing to take on the new and additional work entailed. "The danger is... you tend to travel in a backward direction: the larger the scale, the greater the temptation is to have a body like the Environment Agency managing, because no-one else steps forward... the minute you get the Environment Agency you start to get the top down approach again," (project K).

The past domination of public agencies also had a more subtle effect on the relationships between those agencies and other potential partners and stakeholders. For example, land managers were often suspicious of organizations who had previously been or were still responsible for imposing and enforcing environmental regulations. This caused suspicion and reluctance to cooperate, and perhaps reinforced a tendency to focus on individual interests. Individual groups may also have had a legacy of hostility or problems that impeded their willingness to interact with each other (e.g., project L). Therefore, systemic perspectives might then be impeded because "everyone's representing their own interest group" (project $\mathbf{J}$ ) and discussions could not be "divorced from politics" (project M).

Participatory and holistic approaches to environmental management are quite likely to identify new priorities that differ from existing practices and priorities. Implementing these changes would change the distribution of benefits delivered and thus is likely to be resisted by existing beneficiaries. It was often suspected that taking a systemic perspective was hard for some groups because it was not in their interests. For example, in project D, "It doesn't come naturally to them [land managers] to think about some of the consequences as well as the benefits of certain actions." Quite often, widening the scope of benefits and detriments considered in decision making might produce different priorities than decision making that considered solely profitability. Private businesses, agricultural and otherwise, naturally focus on profit. However, only a narrow range of ecosystem services are priced by markets. Because these new projects did not create new rules, nor did they usually provide new incentives, they often had little power to change existing profitdriven management decisions.

The systems approach is the idea that you systematically
look at all the elements and how they affect each other.
Someone doing that within a business, they tend to take
a business approach; but a systems approach... how do
youget them to lookat someone else's business? A farmer:
how do you get them to stop looking at just food
production, what they do for food, and think about what
they are doing for flood risk or water quality? And how
do you incentivize that and get them to do it? (Project F).

For land management, profitability depends not only on market prices, but also on agricultural subsidies delivered by the European Union's Common Agricultural Policy. However, these schemes are only marginally influenced by environmental policies and are certainly not designed to reflect the latest ideas such as the ecosystem approach. Therefore, for many projects applying for any appropriate options under these schemes was essential, but the schemes poorly matched the priorities and recommendations of the projects.

In summary, the legacy of power and responsibility held by individuals and organizations, and even by different policy areas, seemed a pervasive influence on attempts to implement the new management approach.

Interactions between sticking points

Thus far, we have distinguished institutional (both formal and informal) from cognitive and political sticking points, but we also observed that these overlap with each other. In particular, it often seems difficult to distinguish between ways of working and ways of thinking. For example, is a tradition of land management just about a way of working, or is it also a way of thinking?

In some cases, the sticking points are clearly separate, but they interact sequentially. For example, a struggle to shift to systems thinking can, in turn, impede working in partnerships: "You need to have that understanding in order to have the confidence to marry in agendas by commonality amongst people, and that's difficult for the organization to get that degree of confidence amongst its staff; that's proving to be very difficult," (project D).

Both cognitive and institutional sticking points seem inextricably bound up with the issue of power. In the case of project $J$, "Fishermen quite strongly feel they have a historic right to fish where they want." In this case, whether this perceived right is defined as a cognitive or institutional sticking point, it is doubtless reinforced by a desire to defend existing interests. Similarly, individuals or organizations who hold power over land management are quite commonly perceived as reluctant to engage in new initiatives for environmental management. This arises not just because of their perceptions and preconceptions of environmental issues, but because a new process might result in new priorities that diverge from existing plans and interests, i.e., cognitive and political sticking points reinforce each other. In our sample, when sticking points interacted, the result was always to reinforce resistance to change. For example, limited information 
about a new approach combined with limited power to incentivize new approaches could knowingly or unwittingly reinforce a tendency to prefer existing ways of working. "There's not enough info about how you adapt... there's not that much of a driver there, you could doff your cap and say we're using the ecosystems approach in a fairly easy way, potentially, without radically revising how you operate as an organization," (project D).

These observations on how attempts to change can be constrained fit with the ideas about "closing down" (Stirling 2012). Difficulties in taking more participatory approaches interact with the difficulties of considering new issues, underpinned by a tendency to prefer existing interests. As a result, discussions about new ideas tend to close down and favor existing interests and ways of working.

In our cases, and what goes beyond other studies, the interactions also seem linked to the properties of the natural system. Examples mentioned in our projects include the slow speed of some natural processes versus the time scale of projects, and the likelihood of uncertain and multiple feedback effects resulting from any action: "Often you don't see the results straightaway," (project P). In these situations, it can be hard to persuade other partners and stakeholders to engage, let alone funders. As such, complex, uncertain, and slow natural processes may act to reinforce the other sticking points.

\begin{abstract}
It involves things like the connection of flood zones and shifting - they moved some of the river protections and then let the river do it. And in other areas, they have a kind of complete major restoration project. These sorts of things are particularly difficult to fund... and if you are going to reconnect the floodplain, often people want a longer term security and you get a 10-year agrienvironment agreement; this is a major structural change, but will it still be there in 10 years' time? (Project C).
\end{abstract}

Are sticking points always problematic?

When changes achieved were more incremental than the goals of the ecosystem approach, this was often because of sticking points arising from the legacy of past projects and institutional arrangements. However, the literature suggests that legacy can also provide something positive to build on, and our data support this. In particular, capitalizing on previous knowledge and skills was seen as useful, to help avoid the risk of "reinventing the wheel" (project C). In our data, several projects had experienced a loss of personnel with good networks and contacts, and this was lamented as creating a significant setback for a project (although it may also offer the chance to refresh the skill set of a team). For example, project $G$ struggled to maintain momentum after the loss of its charismatic leader: "People leave... it gets very hard to maintain the continuity of a project."

The ability of the project team to implement work can also be aided if there have been prior projects or initiatives that fostered familiarity in partners working together or interest in environmental issues. In several cases where there had been prior projects, the projects had never encompassed the full range of issues or set of stakeholders required for the new project, but they still offered something useful on which to build. This was often the case in the same projects that experienced challenges due to legacy effects. Similarly, many projects were able to access and use data sets created by previous projects or other initiatives. While those data sets may not perfectly meet the needs of new projects, having access to some data is surely better than having access to none. Thus, it seems important to interpret sticking points as not wholly bad things to be avoided, but rather as something likely to have nuanced implications for the practice of environmental management.

\section{DISCUSSION AND CONCLUSION}

We suggest that it is useful to understand management experiences in terms of sticking points created by legacy effects. Based on the literature on institutional change and our study of attempts to implement the ecosystem approach, it seems a productive way to understand and explore the progress of new projects for environmental management. The projects we studied did make progress in stakeholder participation and working in partnerships for systemic ecosystem management; however, the goals of the ecosystem approach were never fully achieved. We believe this is largely because of different types of legacy effects. For example, attempts to take new systemic approaches are likely to be impeded by factors such as pre-existing rules and targets. Less tangible issues of knowledge and power also interact to close down attempts to do something new (Stirling 2008). Without an appreciation of these effects, implementation of management concepts cannot be fairly and fully understood. We do not claim that legacy is, or should be, the only way in which these experiences can be explored. However, we suggest that legacy is a useful perspective to consider in combination with better established challenges of systemic thinking (Sterling et al. 2010, Rogers et al. 2013) and participatory engagement (Reed 2008). This framing may help in understanding why these other barriers are so hard to resolve.

We have proposed using sticking points rather than terms such as lock-in or path dependency to understand legacy effects. We believe the idea of sticking points is helpful for emphasizing potential interactions and because it does not imply fixed constraints or prescribed responses by the system. For example, in our data, the legacy of past projects and the wider socialecological context did not have a deterministic influence on organizational bureaucracies or the skills and aptitudes of personnel within them. However, our study is exploratory, and further reflection on this concept is needed. In particular, an indepth case study approach is needed to explore fully whether and how the concept of sticking points may benefit the understanding of environmental management.

Regardless of the term used, our observations contribute to the existing literature: What we label as institutional, political, and cognitive sticking points fit with the constraining influences that act to close down debate, as discussed by Stirling (2008). What is apparent in our study, and could be more emphasized by this literature, is that the interactions between these issues could form a critical influence on change. For example, stakeholders' familiarity with focusing on single issues and targets could reinforce a legislative driver to achieve single-issue mandatory targets. Such sticking points could, in turn, potentially reinforce the tendency of some sectors or actors to explicitly resist change, as for example with agriculture in rural settings (Lowe et al. 2010). 
It will be useful to understand how sticking points interact and if they vary according to different institutional settings.

Other issues that require more research are if and how sticking points arise from or are shaped by their interactions with natural processes and systems, and how to distinguish and build on positive vs. negative legacy effects. Neither point has received much attention in the existing studies on legacy effects. Thus, when understanding environmental management projects in terms of sticking points, a special focus on ecological components of systems may be needed. Although there are important gaps in the understanding of these issues, it is possible to use the idea of legacy and sticking points to identify insights for practice. We suggest it will be useful to consider legacy and sticking points during the planning phase. Once they are identified, projects can be planned in such a way to engage with, and where appropriate, overcome them. For example, we found that the need to overcome pre-existing habits of silo working and silo thinking caused some projects to invest in personnel with new networking and communication skills and to seek new partners. Considering sticking points can also help moderate expectations of how quickly any individual project may achieve change, particularly where multiple sticking points must be overcome. This may be important wherever goals for systemic or participatory management are applied to a site or system that was previously managed to achieve one or more statutory targets by naturalscience staff from a single agency.

There are likely to be sticking points that cannot be overcome by individual project managers, e.g., project funding cycles or statutory targets, with implications for policy makers and other actors. This illustrates the need to recognize that responsibility for action lies with multiple actors. This is well described by the literature on multi-level governance (e.g., Newig and Fritsch 2009), but we found that initiatives to promote change were focused at the project level. Because of this, higher level institutions that promote change can also be involved in resisting change. There is a need for formal planning processes across levels to be aware of their role in catalyzing change, but also to be aware that they themselves are shaped by their history (Valve et al. 2013). For example, in our data, organizations whose bureaucracies or mandates were sometimes blamed for impeding change might also fund or support the same or another project. This may relate to different personnel and departments within the same organization, and the fact that some organizations have multiple and potentially conflicting mandates, roles, and identities. Although we know that multiple institutions matter, there is a need to improve the understanding of how multi-level nested actors may potentially play multiple roles to resist and support change.

To improve environmental management, there are many calls for more "transformative" approaches to create pathways for change. Some concepts such as the pathways approach (e.g., Leach et al. $2010 b$ ) are theoretically and empirically grounded in the same literature as legacy effects and sticking points (e.g., Stirling 2008). However, while we agree with the need to plan for change, we argue that these plans will be more successful if we first understand the actual sticking points that are impeding change. Thus, future work to understand institutional, cognitive, and political sticking points and their interactions may not only be useful to help understand challenges, but also how to tackle them.
Successfully introducing radical changes in the way the environment is managed, as entailed by more systemic and participatory approaches, requires more than providing shortterm funding for a new set of projects. To move beyond top-down and technocratic approaches to environmental management, we must consider how the institutional, cognitive, and political context at all levels may constrain or support change. For those people in organizations who seek to fund or encourage new approaches to environmental management, this may imply a new and uncomfortable degree of reflexivity and openness to change. However, the responsibility to implement change and overcome sticking points cannot lie just with project managers. Unless we recognize and tackle the multi-level implications of legacy effects, new approaches to natural resource management will inevitably encounter significant resistance.

Responses to this article can be read online at: http://www.ecologyandsociety.org/issues/responses. $\mathrm{php} / 7594$

\section{Acknowledgments:}

We thank all participants who agreed to be interviewed for this research, E. Banks and E. Hastings for valuable input in the early stages of this project, and all those who have commented on this manuscript. The research for this paper was supported by the Scottish Government RESAS Strategic Research Programme 2011-2016.

\section{LITERATURE CITED}

Adams, W. M. 2009. Editorial introduction to volume 1: the idea of conservation. Pages 1-16 in W. M. Adams, editor. Conservation: volume I: the idea of conservation. Earthscan, London, UK.

Armitage, D. R., R. Plummer, F. Berkes, R. I. Arthur, A. T. Charles, I. J. Davidson-Hunt, A. P. Diduck, N. C. Doubleday, D. S. Johnson, M. Marschke, P. McConney, E. W. Pinkerton, and E. K. Wollenberg. 2009. Adaptive co-management for socialecological complexity. Frontiers in Ecology and the Environment 7(2):95-102. http://dx.doi.org/10.1890/070089

Berkes, F. 2007. Community-based conservation in a globalized world. Proceedings of the National Academy of Sciences 104 (39):15188-15193. http://dx.doi.org/10.1073/pnas.0702098104

Boettke, P. J., C. J. Coyne, and P. T. Leeson. 2008. Institutional stickiness and the New Development Economics. American Journal of Economics and Sociology 67(2):331-358. http://dx.doi. org/10.1111/j.1536-7150.2008.00573.x

Brooks, J. S., K. A. Waylen, and M. Borgerhoff Mulder. 2012. How national context, project design, and local community characteristics influence success in community-based conservation projects. Proceedings of the National Academy of Sciences 109 (52):21265-21270. http://dx.doi.org/10.1073/pnas.1207141110

Brown, K. 2002. Innovations for conservation and development. Geographical Journal 168(1):6-17. http://dx.doi.org/10.1111/1475-4959.00034 
CBD [Convention on Biological Diversity]. 2000. COP 5 decision VI6. Decision adopted by the Conference of Parties to the Convention on Biological Diversity at its 5 th meeting: decision VI6 ecosystem approach. CBD, Nairobi, Kenya. [online] URL: http:// www.cbd.int/decision/cop/?id=7148.

David, P. A. 1985. Clio and the economics of QWERTY. American Economic Review 75(2):332-337. [online] URL: http://www.jstor. org/stable/1805621.

DEFRA [Department for Environment, Food and Rural Affairs]. 2011. The natural choice: securing the value of nature. DEFRA, London, UK. [online] URL: https://www.gov.uk/government/ uploads/system/uploads/attachment data/file/228842/8082.pdf.

Dressler, W., B. Büscher, M. Schoon, D. Brockington, T. Hayes, C. A. Kull, J. McCarthy, and K. Shrestha. 2010. From hope to crisis and back again? A critical history of the global CBNRM narrative. Environmental Conservation 37(1):5-15. http://dx.doi. org/10.1017/s0376892910000044

Fazey, I., J. A. Fazey, J. G. Salisbury, D. B. Lindenmayer, and S. Dovers. 2006. The nature and role of experiential knowledge for environmental conservation. Environmental Conservation 33 (1):1-10. http://dx.doi.org/10.1017/S037689290600275X

Fischhendler, I., and T. Heikkila. 2010. Does integrated water resources management support institutional change? The case of water policy reform in Israel. Ecology and Society 15(1): 4. [online] URL: http://www.ecologyandsociety.org/vol15/iss1/art4/.

Fish, R. D. 2011. Environmental decision making and an ecosystems approach: some challenges from the perspective of social science. Progress in Physical Geography 35(5):671-680. http://dx.doi.org/10.1177/0309133311420941

Folke, C., T. Hahn, P. Olsson, and J. Norberg. 2005. Adaptive governance of social-ecological systems. Annual Review of Environment and Resources 30:441-473. http://dx.doi.org/10.1146/ annurev.energy.30.050504.144511

Gómez, E. J. 2011. An alternative approach to evaluating, measuring, and comparing domestic and international health institutions: insights from social science theories. Health Policy 101(3):209-219. http://dx.doi.org/10.1016/j.healthpol.2010.08.020

Grabher, G. 1993. The weakness of strong ties: the lock-in of regional development in the Ruhr area. Pages 255-277 in G. Grabher, editor. The embedded firm: on the socioeconomics of industrial networks. Routledge, London, UK.

Greener, I. 2005. The potential of path dependence in political studies. Politics 25(1):62-72. http://dx.doi.org/10.1111/ j.1467-9256.2005.00230.x

Hall, P. A., and R. C. R. Taylor. 1996. Political science and the three new institutionalisms. Political Studies 44(5):936-957. http:// dx.doi.org/10.1111/j.1467-9248.1996.tb00343.x

Harries, T., and E. Penning-Rowsell. 2011. Victim pressure, institutional inertia and climate change adaptation: the case of flood risk. Global Environmental Change 21(1):188-197. http://dx. doi.org/10.1016/j.gloenvcha.2010.09.002

Howard, B., K. A. Waylen, and K. L. Blackstock. 2013. Does the ecosystem approach offer anything new for environmental decision- making? Report from the RGS-IBG conference workshop held on 29th August, 2013. NERC Centre for Ecology and Hydrology, Wallingford, UK, and James Hutton Institute, Aberdeen, UK. [online] URL: http://ecosystemsknowledge.net/sites/default/files/ wp-content/uploads/2013/12/RGS EcosystemApproach Session2 FINAL.pdf.

Huitema, D., and S. Meijerink. 2010. Realizing water transitions: the role of policy entrepeneurs in water policy change. Ecology and Society 15(2): 26. [online] URL: http://www.ecologyandsociety. org/vol15/iss $2 /$ art26/.

Imperial, M. T. 1999. Institutional analysis and ecosystem-based management: the institutional analysis and development framework. Environmental Management 24(4):449-465. http://dx. doi.org/10.1007/s002679900246

Ingram, H., and L. Fraser. 2006. Path dependency and adroit innovation: the case of California water. Pages 78-109 in R. Repetto, editor. Punctuated equilibrium and the dynamics of U.S. environmental policy. Yale University Press, New Haven, Connecticut, USA.

Kates, R. W., W. R. Travis, and T. J. Wilbanks. 2012. Transformational adaptation when incremental adaptations to climate change are insufficient. Proceedings of the National Academy of Sciences 109(19):7156-7161. http://dx.doi.org/10.1073/ pnas. 1115521109

Kaufmann, A., and F. Tödtling. 2001. Science-industry interaction in the process of innovation: the importance of boundary-crossing between systems. Research Policy 30 (5):791-804. http://dx.doi.org/10.1016/S0048-7333(00)00118-9

Kay, A. 2005. A critique of the use of path dependency in policy studies. Public Administration 83(3):553-571. http://dx.doi. org/10.1111/j.0033-3298.2005.00462.x

Kirk, E., A. Reeves, and K. Blackstock. 2007. Path dependency and the implementation of environmental regulation. Environment and Planning C: Government and Policy 25 (2):250-268. http://dx.doi.org/10.1068/c0512j

Lackey, R. T. 1998. Seven pillars of ecosystem management. Landscape and Urban Planning 40(1-3):21-30. http://dx.doi. org/10.1016/S0169-2046(97)00095-9

Leach, M. 2010. The pathways approach of the STEPS Centre. University of Sussex, Brighton, UK. [online] URL: http://stepscentre.org/wp-content/uploads/STEPS Pathways online1.pdf.

Leach, M., I. Scoones, and A. Stirling. 2010a. Dynamic sustainabilities: technology, environment, socialjustice. Earthscan, London, UK.

Leach, M., I. Scoones, and A. Stirling. 2010b. Governing epidemics in an age of complexity: narratives, politics and pathways to sustainability. Global Environmental Change 20 (3):369-377. http://dx.doi.org/10.1016/j.gloenvcha.2009.11.008

Lowe, P., P. H. Feindt, and H. Vihinen. 2010. Greening the countryside? Changing frameworks of EU agricultural policy. Public Administration 88(2):287-295. http://dx.doi.org/10.1111/ j.1467-9299.2010.01835.x

Meer, T., and M. A. Schnurr. 2013. The community versus community-based natural resource management: the case of 
Ndumo game reserve, South Africa. Canadian Journal of Development Studies 34(4):482-497. http://dx.doi. org/10.1080/02255189.2013.849580

Meijerink, S., and D. Huitema. 2009. Understanding and managing water policy transitions: a policy science perspective. Pages 23-36 in D. Huitema and S. Meijerink, editors. Water policy entrepreneurs: a research companion to water transitions around the globe. Edward Elgar, Cheltenham, UK.

Miller, B. W., S. C. Caplow, and P. W. Leslie. 2012. Feedbacks between conservation and social-ecological systems. Conservation Biology 26(2):218-227. http://dx.doi.org/10.1111/j.1523-1739.2012.01823. $\underline{\mathrm{X}}$

Newig, J., and O. Fritsch. 2009. Environmental governance: participatory, multi-level - and effective? Environmental Policy and Governance 19(3):197-214. http://dx.doi.org/10.1002/eet.509

North, D. C. 1990. Institutions, institutional change and economic performance. Cambridge University Press, Cambridge, UK.

Ostermann, O. P. 1998. The need for management of nature conservation sites designated under Natura 2000. Journal of Applied Ecology 35(6):968-973. http://dx.doi.org/10.1111/ j.1365-2664.1998.tb00016.x

Paavola, J., and K. Hubacek. 2013. Ecosystem services, governance, and stakeholder participation: an introduction. Ecology and Society 18(4): 42. http://dx.doi.org/10.5751/ es-06019-180442

Pahl-Wostl, C., G. Holtz, B. Kastens, and C. Knieper. 2010. Analyzing complex water governance regimes: the Management and Transition Framework. Environmental Science and Policy 13 (7):571-581. http://dx.doi.org/10.1016/j.envsci.2010.08.006

Reed, M. S. 2008. Stakeholder participation for environmental management: a literature review. Biological Conservation 141 (10):2417-2431. http://dx.doi.org/10.1016/j.biocon.2008.07.014

Rogers, K. H., R. Luton, H. Biggs, R. Biggs, S. Blignaut, A. G. Choles, C. G. Palmer, and P. Tangwe. 2013. Fostering complexity thinking in action research for change in social-ecological systems. Ecology and Society 18(2): 31. http://dx.doi.org/10.5751/ ES-05330-180231

Schienstock, G. 2007. From path dependency to path creation: Finland on its way to the knowledge-based economy. Current Sociology 55(1):92-109. http://dx.doi.org/10.1177/0011392107070136

Silverman, D., editor. 2004. Qualitative research: theory, method and practice. Second edition. Sage, London, UK.

Skocpol, T., and P. Pierson. 2002. Historical institutionalism in contemporary political science. Pages 693-721 in I. Katznelson and H. V. Milner, editors. Political science: state of the discipline. W.W. Norton, New York, New York, USA.

Sterling, E. J., A. Gómez, and A. L. Porzecanski. 2010. A systemic view of biodiversity and its conservation: processes, interrelationships, and human culture. Bioessays 32(12):1090-1098. http://dx.doi.org/10.1002/bies.201000049

Stirling, A. 2008. "Opening up" and "closing down": power, participation, and pluralism in the social appraisal of technology. Science, Technology and Human Values 33(2):262-294. http://dx. doi.org/10.1177/0162243907311265
Stirling, A. 2012. Opening up the politics of knowledge and power in bioscience. PLoS Biology 10(1): e1001233. http://dx.doi. org/10.1371/journal.pbio.1001233

Strauss, A. L., and J. M. Corbin. 1998. Basics of qualitative research: techniques and procedures for developing grounded theory. Second edition. Sage, London, UK.

Thrane, S., S. Blaabjerg, and R. H. Møller. 2010. Innovative path dependence: making sense of product and service innovation in path dependent innovation processes. Research Policy 39 (7):932-944. http://dx.doi.org/10.1016/j.respol.2010.04.003

Uzzi, B. 1996. The sources and consequences of embeddedness for the economic performance of organizations: the network effect. American Sociological Review 61(4):674-698. [online] URL: http://www.jstor.org/stable/2096399.

Valve, H., M. Åkerman, and M. Kaljonen. 2013. 'You only start filling in the boxes': natural resource management and the politics of plan-ability. Environment and Planning A 45(9):2084-2099. http://dx.doi.org/10.1068/a45219

Vatn, A. 2010. An institutional analysis of payments for environmental services. Ecological Economics 69(6):1245-1252. http://dx.doi.org/10.1016/j.ecolecon.2009.11.018

von Hippel, E. 1994. "Sticky information" and the locus of problem solving: implications for innovation. Management Science 40(4):429-439. http://dx.doi.org/10.1287/mnsc.40.4.429

Watson, G. 1971. Resistance to change. American Behavioral Scientist 14(5):745-766. http://dx.doi.org/10.1177/000276427101400507

Waylen, K. A., K. L. Blackstock, and K. L. Holstead. 2013. Exploring experiences of the ecosystem approach. Project report by the James Hutton Institute, Aberdeen, UK. [online] URL: http://www.hutton.ac.uk/sites/default/files/files/ecosystemservices/ Report on EcA review Final.pdf.

Waylen, K. A., E. J. Hastings, E. A. Banks, K. L. Holstead, R. J. Irvine, and K. L. Blackstock. 2014. The need to disentangle key concepts from "ecosystem-approach" jargon. Conservation Biology 28(5):1215-1224. http://dx.doi.org/10.1111/cobi.12331

Western, D., M. R. Wright, and S. C. Strum, editors. 1994. Natural connections: perspectives in community-based conservation. Island Press, Washington, D.C., USA.

Wilsford, D. 1994. Path dependency, or why history makes it difficult but not impossible to reform health care systems in a big way. Journal of Public Policy 14(3):251-283. http://dx.doi. org/10.1017/S0143814X00007285

Wilshusen, P. R., S. R. Brechin, C. L. Fortwangler, and P. C. West. 2002. Reinventing a square wheel: critique of a resurgent "protection paradigm" in international biodiversity conservation. Society and Natural Resources 15(1):17-40. http://dx.doi. org/10.1080/089419202317174002

Young, O. R. 2002. The institutional dimensions of environmental change: fit, interplay, and scale. MIT Press, Cambridge, Massachusetts, USA. 
Appendix 1. Topic headings used to guide information collection during review of Ecosystem Approach projects

Part A: Headings within proforma used to structure collection of information from documentary sources. Links to original sources were used and cross-referenced during analysis.

Project name

Project objectives and rationale

Main actions by which project objectives are to be achieved

Policy drivers /influences

Scale(s) and boundaries of case study

Natural habitats/land use classes involved

Resource tenure and management

Resource uses, beneficiaries and conflicts

Time scales for project

Funding sources for project

Project team and partners

Who said it was an Ecosystem Approach, and how is it defined/understood

Ecosystem Services considered

Framework used in case study

Tools and techniques used within the project

Levers (sanctions, incentives, voluntary action, education/awareness raising)

Stakeholders involved and how

Mixture of knowledges used and how

Project actions/achievements/outputs to date

Monitoring and Evaluation used 
Part B: Headings within interview guide used to explore experiences of the Ecosystem Approach

\section{Introduction}

Information about why we are doing the research; how the information will be used and a check that we have your informed consent to proceed.

\section{About the project}

We have filled in a short project information note using information from your website. This will be updated and sent to you post interview for checking, so this section will just double check some summary points about:

- The project objectives

- The main policy drivers

- Project timelines

\section{Decision to adopt an Ecosystem Approach}

Discussion of why you would call your project an Ecosystem Approach; and/or some other label, and why the particular approach was adopted.

\section{Reflecting on what the approach has achieved}

Achievements of the project to date; the benefits (or not) of approach taken; and what lessons could be learnt for implementing an ecosystem approach in Scotland.

\section{Your experiences of the project}

Discussion of the practical implementation issues arising from the project including:

- Shared understandings of problem and opportunities

- Guidance or access to existing expertise in the approach

- Organisation or governance of the project

- Fit with existing policies and 'institutions' (i.e. formal and informal rules of how things are done)

- Access to resources

- Availability or lack of availability of data

- Types of knowledge drawn upon

- Monitoring and evaluation

- Thinking systemically

- Awareness of an ecosystems approach

- Terminology of an ecosystem approach

- Managing trade-offs

\section{What happens next}

Information about finalising the data collection and when the results will be returned to you. 